\title{
MENINGKATAN KEMAMPUAN KETERAMPILAN BERBICARA SISWA MELALUI METODE DISKUSI KELOMPOK DI KELAS V SD NEGERI 2 KATOBENGKE
}

\author{
Karim \\ Dinas Pendidikan, Pemuda, dan Olahraga Kota Baubau, SD Negeri 2 Katobengke \\ E-mail: karim.sd2katobengke@gmail.com
}

\begin{abstract}
Abstrak
Tujuan penelitian ini adalah untuk mengetahui efektivitas metode diskusi kelompok untuk meningkatkan kemampuan keterampilan berbicara siswa kelas V SD Negeri 2 Katobengeke. Subjek penelitian ditetapkan dikelas V SD Negeri 2 Katobengke dengan jumlah peserta didik sebesar 20 orang. Hasil penelitian menunjukan bahwa hasil Belajar siswa kelas V SD Negeri 2 Katobengke dalam proses belajar mengajar Bahasa Indonesia melalui pembelajaran metode diskusi kelompok secara efektif mengalami peningkatan pada, aktifitas siswa, guru dan hasil belajar yaitu, tuntas secara klasikal dan secara individu.
\end{abstract}

Kata kunci: berbicara, diskusi, keterampilan.

\begin{abstract}
The purpose of this study was to determine the effectiveness of group discussion methods to improve students' speaking skills class $V$ SD Negeri 2 Katobengeke. The research subject is set in class V SD Negeri 2 Katobengke by the number of students by 20 people. The results showed that the results of Study fifth grade students of SD Negeri 2 Katobengke in the learning process through learning Indonesian group discussion method is effectively an increase in, the activities of students, teachers and learning outcomes, namely, complete classically and individually.
\end{abstract}

Keywords: talk, discussion, skills. 


\section{SANG PENCERAH}

Volume 4, Nomor 1, Februari 2018, Hlm. 5-11

Karim: Meningkatkan Kemampuan Keterampilan Berbicara Siswa ...

\section{Pendahuluan}

Dalam pendidikan formal peranan guru sangat penting, sebab berhasil tidaknya kegiatan belajar mengajar sangat ditentukan oleh kemampuan guru dalam mentransfer pengetahuan yang diharapkan dapat dipahami siswa. Olehnya itu, salah satu faktor yang dapat membantu guru dalam mentransfer pengetahuan kepada siswa, yakni menggunakan metode dan media pengajaran yang relevan sebagai alat bantu dalam kegiatan belajar mengajar. Metode diskusi lebih berperan dalam pengajaran yang dikolaborasikan dengan metode lain yang relevan dan digunakan dalam proses pembelajaran. Menurut Yamin (2013:8) bahwa metode pembelajaran merupakan bagian dari strategi instruksional, metode instruksional berfungsi sebagai cara untuk menyajikan, menguraikan, memberi contoh, dan memberi latihan kepada peserta didik untuk mencapai tujuan tertentu, tetapi tidak setiap metode instruksional sesuai digunakan untuk mencapai tujuan instruksional tertentu. Banyak metode instruksional yang dapat digunakan dalam menyajikan pelajaran kepada siswa-siswa, seperti metode ceramah, metode tanyajawab, metode demonstrasi, metode eksperimen, metode tugas, dan sebagainya.

Dalam proses belajar mengajar guru dihadapkan untuk memilih metode-metode dari sekian banyak metode yang telah ditemui oleh para ahli, sebelum menyampaikan materi pengajaran untuk mencapai tujuan kompetensi. Beberapa pertimbangan yang mesti dilakukan oleh guru dalam memilih materi pengajaran secara tepat dan akurat, pertimbangan tersebut mesti berdasarkan pada penetapan. Metode diskusi merupakan interaksi antara siswa dengan siswa atau antara guru dengan siswa untuk menganalisis, memecahkan masalah, menggali atau memperdebatkan topik atau permasalahan tertentu. Menurut Sabri (2007:54) menyatakan bahwa diskusi suatu kegiatan kelompok untuk memecahkan suatu masalah dengan maksud untuk mendapat pengertian bersama yang lebih jelas dan lebih teliti tentang sesuatu, atau untuk menampung keputusan bersama. Dalam diskusi, tiap orang diharapkan memberikan sumbangan sehingga seluruh kelompok kembali dengan pemahaman yang sama dalam suatu keputusan atau kesimpulan.

Keterampilan berasal dari kata "terampil" kemudian mendapat awalan Kedan akhiran -an, Keterampilan mengandung pengertian mampu dan cekatan sedangkan berbicara berasal dari kata "bicara" yang ditambah dengan awalan Ber- yang mengandung pengertian berkata, akal budi, pikiran atau pendapat. Selanjutnya yang dimaksud metode diskusi adalah suatu bentuk metode yang digunakan dalam proses pembelajaran merupakan interaksi antara siswa atau antara guru dengan siswa untuk menganalisis, memecahkan masalah, menggali atau memperdebatkan topik atau permasalahan tersebut, dalam kaitan dengan penelitian ini yang menjadi topik adalah keterampilan berbicara. Pendekatan kelompok diskusi menekankan diskusi tentang gagasan abstrak dan sintesis atau gagasan yang berbeda-beda atau pandangan atas sebuah tema kedalam unit pelajaran yang kompleks. Menurut Bejanaro (dalam sharan, 2012:342) menyatakan bahwa pengajaran kooperatif kelompok kecil memajukan pencapaian bahasa yang lebih tinggi dibandingkan dengan pengajaran langsung bimbingan guru karena digunakannya pendekatan komunikatif. Penelitian ini menunjukkan bahwa metode kelompok diskusi lebih efisien untuk melatih ketrampilan berbahasa secara umum, seperti mendengarkan dan berbicara. Metode teknik ini mengaktifkan berbagai proses kelompok dan akibatnya mempengaruhi prilaku siswa secara berbeda-beda, selain fitur-fitur interaksi kelompok kecil mereka yang telah lazim dan bantuan timbal balik yang ada diantara 


\section{SANG PENCERAH}

Volume 4, Nomor 1, Februari 2018, Hlm. 5-11

\section{Karim: Meningkatkan Kemampuan Keterampilan Berbicara Siswa ...}

kedua kelmpok. Jika ditinjau dari Siswa, maka banyak faktor-faktor yang perlu mendapat perhatian, lebih-lebih hubungannya dengan belajar Bahasa Indonesia. Bahasa Indonesia bagi siswa pada umumnya merupakan pelajaran yang kurang disenangi karena kurangnya antusias siswa terhadap pelajaran ini. Oleh karena itu, dalam interaksi belajar mengajar bahasa Indonesia seorang guru harus memperhatikan faktor-faktor yang menyangkut siswa diantaranya kecerdasan, minat, dan suasana pembelajaran Berdasarkan pengamatan peneliti dalam proses pembelajaran di kelas V SD Negeri 2 Katobengke menunjukkan bahwa berbicara dalam diskusi kelompok merupakan keterampilan berbahasa yang dianggap sulit. Hal ini dipengaruhi oleh faktor kesiapan siswa dalam mengikuti materi. Hal ini dibuktikan dengan nilai mata pelajaran bahasa Indonesia yang masih kurang khususnya keterampilan berbicara. Nilai rata-rata siswa dalam mata pelajaran bahasa Indonesia khususnya keterampilan berbicara dalam diskusi kelompok rata-rata 60. Nilai tersebut tidak mencapai KKM (Kriteria Ketuntasan Minimal) untuk mata pelajaran bahasa Indonesia khususnya berbicara adalah 65. Berdasarkan deskripsi di atas, fokus penelitian ini adalah bagaimana meningkatkan kemampuan keterampilan berbicara siswa melalui metode diskusi kelompok di kelas V SD Negeri 2 Katobengeke?

Tujuan penelitian ini adalah untuk mengetahui efektivitas metode diskusi kelompok untuk meningkatkan kemampuan keterampilan berbicara siswa kelas V SD Negeri 2 Katobengeke.

\section{Metode Penelitian}

\section{Subjek Penelitian}

Berdasarkan pendapat Zainal Aqib (2011:19) menyatakan bahwa sampel penelitian atau subjek penelitian ditetapkan berdasarkan suatu permasalahan yang akan dijawab melalui suatu tindakan. Berdasarkan pengamatan penulis dan penelitian pratindakan diperoleh permasalahan dikelas V. Sehingga berdasarkan permasalahan tersebut maka subjek penelitian ditetapkan dikelas V SD Negeri 2 Katobengke dengan jumlah peserta didik sebesar 20 orang.

\section{Rencana Tindakan}

Jenis penelitian ini termasuk dalam penelitian tindakan (action research) yang berbentuk Penelitian Tindakan Kelas (PTK), secara bersiklus terdiri dari Perencanaan, Tindakan, observasi dan Refleksi. Penelitian ini diarahkan untuk memecahkan masalah atau perbaikan yang berhubungan dengan masalah-masalah dikelas. Penelitian ini difokuskan kepada perbaikan proses maupun peningkatan hasil kegiatan. Setiap siklus terdiri dari empat tahap yang mengacu pada model kemmis dan Mc Taggar (Depdiknas, 2005:6), yaitu rencana, tindakan, observasi, dan refleksi. Penelitian ini dilakukan selama dua bulan mulai pada bulan Maret - April 2014.

\section{Jenis, Teknik Pengumpulan Data}

Jenis data yang didapatkan dalam penelitian ini adalah data kualitatif dan kuantitatif.

1. Data kualitatif, yaitu data yang diperoleh dari aktifitas siswa dan akifitas guru berupa data hasil observasi dan hasil wawancara;

2. Data kuantitatif, yaitu data yang diperoleh dari hasil tes yang diberikan kepada siswa.

Teknik pengumpulan data dalam penelitian tindakan kelas ini adalah sebagai berikut.

\section{a. Observasi}

Observasi dilakukan untuk mengetahui proses pembelajaran pemahaman dalam pembelajaran bahasa Indonesia dengan menggunakan metode 


\section{SANG PENCERAH}

Volume 4, Nomor 1, Februari 2018, H1m. 5-11

Karim: Meningkatkan Kemampuan Keterampilan Berbicara Siswa ...

demonstrasi di kelas V SD Negeri 2 Katobengke. Pedoman observasi pada penelitian ini dititik beratkan pada pengamatan aspek-aspek pemahaman siswa selama pelaksanaan proses pembelajaran. Data observasi dilengkapi dengan format atau blangko pengamatan dan penilaian aktivitas siswa dan guru.

\section{b. Wawancara}

Wawancara dilakukan untuk mengetahui hal-hal yang kurang bisa diamati pada saat observasi. Pertanyaanpertanyaan yang diajukan disusun dengan pedoman tertentu mengacu pada aspek atau hal-hal yang akan di teliti, dalam hal ini adalah pemahaman siswa pada pembelajaran bahasa Indonesia.

\section{c. Dokumentasi}

Dokumen digunakan untuk memperkuat data yang diperoleh dalam pelaksanaan observasi. Dokumen yang digunakan berupa daftar hadir siswa siswa dalam mengikuti pembelajaran Bahasa Indonesia, daftar nilai siswa baik berupa nilai ulangan harian maupun nilai semester yang pernah diperoleh siswa sehingga pemahaman siswa dalam pembelajaran bahasa Indonesia diperoleh gambaran secara konggrit tentang peningkatannya dan pelaksanaan kegiatan pembelajaran yang dilakukan guru; Wawancara dilakukan baik kepada guru mitra maupun siswa untuk Mengetahui sejauh mana kemampuan peamahan bahasa Indonesia dengan menggunakan metode demonstrasi yang dilakukan guru. Sedangkan dokumentasi dijadikan sebagai bahan penguatan dan evaluasi terhadap pelaksanaan kegiatan belajar dan mengajar dalam mendukung pelaksanaan penelitian. Hasilnya dipergunakan untuk memperoleh data tentang kemampuan pemahaman dalam pembelajaran bahasa Indonesia dengan menggunakan metode demonstrasi dikelas V SD Negeri 2 Katobengke.

\section{Teknik Analisis Data}

Teknik analisis data yang digunakan oleh model alur, yaitu reduksi data, penyajian data, dan penarikan kesimpulan (Milles \& Huberman, 1989). Adapun teknik pengumpulan data adalah sebagai berikut:

\section{Teknik Analisis Data Kualitatif}

Analisis data dalam penelitian ini dilakukan setelah pengumpulan data. Adapun tahap-tahap kegiatan analisis data kualitatif adalah (1) mereduksi data; (2) menyajikan data; (3) penarikan kesimpulan dan ferifikasi.

\section{a. Mereduksi Data}

Mereduksi data adalah proses kegiatan menyeleksi, memfokuskan dan menyederhanakan semua data yang telah diperoleh mulai dari awal pengumpulan data sampai pada penyusunan laporan penelitian.

\section{b. Penyajian Data}

Penyajian dilakukan dalam
rangka mengorganisasikan hasil
reduksi dengan cara menyusun naratif
sekumpulan informasi yang telah
diperoleh dari hasil reduksi sehingga
dapat memberikan kemungkinan
penarikan kesimpulan dan penarikan
tindakan. Informasi adalah uraian
proses kegiatan pembelajaran, aktifitas
atau kinerja siswa, terhadap kegiatan
pembelajaran serta hasil yang
diperoleh dari data hasil observasi.
Data yang disajikan tersebut
selanjutnya dibuat penafsiran dan
evaluasi untuk membuat perencanaan
tindakan selanjutnya.

Teknik Analisis data kuantitatif yang digunakan dalam penelitian tindakan kelas (PTK) ini adalah hasil belajar. Dengan demikian akan ditentukan indikator hasil belajar siswa. Berdasarkan indikator hasil belajar siswa dapat dilihat pada bagian 


\section{SANG PENCERAH}

Volume 4, Nomor 1, Februari 2018, Hlm. 5-11

\section{Karim: Meningkatkan Kemampuan Keterampilan Berbicara Siswa ...}

obsevasi untuk siswa di atas, lalu ditentukan frekuensinya atau jumlah siswa. Dari sini dihitung berdasarkan rumus presentase ketuntasan belajar siswa dengan menggunakan rumus.

\section{a. Daya Serap Individu(DSI)}

Analisis data untuk mengetahui daya serap masing-masing siswa digunakan rumus sebagai berikut:

$$
\text { DSI }=\frac{x}{y} \times 100
$$

\section{Keterangan}

$$
\begin{aligned}
& \mathrm{X}=\text { skor yang diperoleh siswa } \\
& \mathrm{Y}=\text { skor maksimal soal } \\
& \text { DSI = daya serap individu }
\end{aligned}
$$

Seorang siswa dikatakan tuntas belajar secara individu jika prosentase daya serap individu sekurang-kurangnya $65 \%$ (Depdiknas, 2001:37)

\section{b. Ketuntasan Belajar secara Klasikal (KBK)}

$$
\mathrm{KBK}=\frac{\sum_{\mathrm{N}}}{\sum_{\mathrm{S}}} \times 100
$$

Keterangan

$\mathrm{N}=$ Jumlah siswa yang tuntas

$\mathrm{S}=$ Jumlah siswa peserta tes

KBK= Ketuntasan Belajar Klasikal

Suatu kelas dikatakan tuntas belajar klasikal apabila rata-rata $80 \%$ siswa telah tuntas secara individual (Depdiknas, 2001:37).

\section{Pembahasan}

\section{Deskripsi Hasil Penelitian}

\section{Keaktifan Siswa}

Hasil observasi aktivitas siswa dalam proses belajar mengajar pada setiap siklus diamati melalui aspek siswa memberikan respon saat guru memberikan apersepsi, Siswa mendengarkan penjelasan materi yang disampaikan oleh guru, Siswa mengerjakan LKS, Siswa berdiskusi dengan kelompok, Siswa menggunakan pembelajaran metode diskusi kelompok dan siswa mempresentasekan hasil diskusi kelompok. Aktivitas siswa dalam proses pembelajaran pada siklus I pertemuan 1 diperoleh jumlah rata-rata prosentase $45,83 \%$ dan siklus I pertemuan II diperoleh rata-rata prosentase 50,00\%, serta siklus II, pertemuan I berdasarkan kriteria yang telah ditetapkan menunjukan bahwa aktivitas belajar siswa berada pada kategori sangat Baik atau terjadi peningkatan dari siklus I ke siklus II sebesar 41,67\%. Dengan demikian aktivitas siswa dalam pelaksanaan pembelajaran telah terjadi peningkatan 9,17\% dari siklus I ke siklus II. Artinya terjadi peningkatan aktivitas siswa dalam proses pembelajaran yang dilaksanakan di mana pada siklus II diperoleh nilai rata-rata prosentase 80,42 $\%$ atau berada pada kriteria Baik dari indicator yang telah ditetapkan.

\section{Aktivitas Guru}

Hasil partisipasi guru dalam proses pembelajaran dari siklus I ke siklus II menunjukan adanya peningkatan yang cukup berartii yakni dari rata-rata hasil aktivitas guru pada siklus I sebesar 57,5\% naik menjadi $80 \%$ pada siklus II atau naik sebesar 22,5\% ini artinya bahwa partisipasi guru pada siklus II telah tercapai sesuai dengan indikator kinerja yang di tetapkan dalam penelitian atau berada pada kategori Baik. 


\section{SANG PENCERAH}

Volume 4, Nomor 1, Februari 2018, Hlm. 5-11

Karim: Meningkatkan Kemampuan Keterampilan Berbicara Siswa ...

\section{Hasil Belajar}

Hasil belajar Bahasa Indonesia, dari siklus I ke siklus II memperlihatkan adanya peningkatan yang cukup berarti yakni dari rata-rata hasil belajar siklus I sebesar 71,25 naik menjadi 80,42 pada siklus II atau mengalami peningkatan sebesar 9,17\%. Akan halnya pada ketuntasan hasil belajar secara klasikal dari $60 \%$ pada siklus I meningkat menjadi $85 \%$ pada siklus II atau mengalami peningkatan sebesar $25 \%$. Artinya bahwa hasil yang diperoleh tersebut telah memenuhi kriteria ketuntasan belajar siswa secara klasikal sebagaimana yang telah ditetapkan pada indikator penelitian ini yaitu sebesar $80 \%$ dan ketuntasan hasil belajar individu sebesar $65 \%$.

Berdasarkan hasil yang di capai oleh siswa tersebut, maka dapat dikatakan bahwa hasil belajar siswa pada pembelajaran Bahasa Indonesia dapat ditingkatkan melalui pendekatan pembelajaran metode diskusi kelompok di kelas V SD Negeri 2 Katobengke. Hasil yang diperoleh pada hasil belajar siswa, Aktivitas siswa dan aktivitas guru pada siklus II menunjukan peningkatan yang signifikan hal ini disebabkan karena penggunaan pembelajaran Metode diskusi kelompok telah terlaksana dengan baik dan efektif dalam proses belajar megajar Bahasa Indonesia di kelas V SD Negeri 2 Katobengke. Dengan demikian bahwa penelitian dinyatakan berhasil.

\section{Simpulan}

Simpulan penelitian ini bahwa hasil Belajar siswa kelas V SD Negeri 2 Katobengke dalam proses belajar mengajar Bahasa Indonesia melalui pembelajaran metode diskusi kelompok secara efektif mengalami peningkatan pada, aktifitas siswa, guru dan hasil belajar yaitu, tuntas secara klasikal dan secara individu.

\section{Daftar Pustaka}

Arikunto, Suharsimi. 1997. Prosedur Penelitian: Suatu Pendekatan Praktek. Jakarta: Rineka Cipta.

Arsyad, Azhar. 2002. Media Pembelajaran. Jakarta: PT Raja Grafindo Persada

Depdiknas. 2005. Pembelajaran Efektif. Jakarta: Depdiknas.

Martinis, Yani. 2013. Strategi dalam Model Pembelajaran. Jambi.

Sabri, Ahmad. 2007. Strategi Belajar Mengajar dan Micro Teaching. Jakarta: Quantum Teaching.

Sharan, Shomo. 2012. The Hand Back Of Cooverative Learning. London: Wesport, Convection.

Salvin Robert. 2000. Education Psychology. Sixth Edition. Boston: Reidel Publishing.

S. Sadiman, Arief, dkk. 1989. Media Pendidikan, Pengertian, Pengembangan dan Pemanfaatanya. Jakarta: Pustekom Dikbud \& CV. Rajawali.

Pengertian Pengembangan dan
Pemanfaatannya. Jakarta: PT Raja
Grafindo Persada.

Sardiman. 2006. Interaksi dan Motivasi Belajar Mengajar. Jakarta: PT Raja Gafinda Persada.

Slameto. 2003. Belajar dan Faktor-Faktor yang Mempengaruhinya. Jakarta: Rineka Cipta. 


\section{SANG PENCERAH}

Volume 4, Nomor 1, Februari 2018, Hlm. 5-11

Karim: Meningkatkan Kemampuan Keterampilan Berbicara Siswa ...

Undang-Undang RI Nomor 20 Tahun 2003

Tentang Sistem Pendidikan Nasional. 